\title{
Effect of Milking Frequency and Diet on Milk Production, Energy Balance, and Reproduction in Dairy Cows
}

\author{
J. Patton, ${ }^{\star}$ D. A. Kenny,† J. F. Mee, ${ }^{\star}$ F. P. O’Mara,† D. C. Wathes,‡ M. Cook, $\ddagger$ and J. J. Murphy ${ }^{\star 1}$ \\ *Teagasc Moorepark, Dairy Production Research Centre, Fermoy, Co. Cork, Ireland \\ †School of Agriculture, Food Science and Veterinary Medicine, College of Life Sciences, University College Dublin, Ireland \\ ‡Department of Veterinary Basic Sciences, Royal Veterinary College, University of London, Hatfield, United Kingdom
}

\section{ABSTRACT}

The objective of this study was to determine the effects of reduced milking frequency and increased dietary energy density in early lactation on milk production, energy balance, and subsequent fertility. Sixtysix spring-calving, multiparous Holstein-Friesian cows were assigned to 1 of 3 treatment groups: once-daily milking on a standard diet ( $1 \times \mathrm{ST})$; 3 -times daily milking on a standard diet ( $3 \times \mathrm{ST})$; and 3 -times daily milking on a high-energy diet. Treatments were imposed for the first $28 \mathrm{~d}$ of lactation, after which all groups were milked twice daily and fed the standard diet. During the treatment period, the $1 \times \mathrm{ST}$ cows had $19.6 \%$ lower milk yield and higher milk fat and milk protein concentrations (15.7 and $10.2 \%$, respectively) compared with $3 \times$ ST. Dry matter (DM) intake was similar between $1 \times \mathrm{ST}$ and $3 \times \mathrm{ST}$ during the treatment period (12.64 vs. $13.25 \mathrm{~kg} /$ $\mathrm{d}$; SED $=0.82$ ). Daily energy balance was less negative for $1 \times \mathrm{ST}$ compared with $3 \times \mathrm{ST}$ during wk 1 to 3 of lactation $[-3.92$ vs. -5.30 unité fourragère lait (UFL)/d; $\mathrm{SED}=0.65 ; 1 \mathrm{UFL}$ is equal to the net energy for lactation of $1 \mathrm{~kg}$ of standard air-dry barley]. During the treatment period, the cows on the high-energy diet had $17 \%$ higher milk yield, higher DM intake (15.5 vs. 13.9 $\mathrm{kg} / \mathrm{d}$; SED $=0.71)$, and similar energy balance $(-4.45$ vs. $-4.35 \mathrm{UFL} / \mathrm{d}$; SED $=0.65)$ compared to $3 \times \mathrm{ST}$. Diet had no significant effect on any of the fertility variables measured. The interval to first ovulation was shorter for $1 \times$ ST than $3 \times \mathrm{ST}(18.3 \mathrm{~d}$ vs. $28.6 \mathrm{~d}$; SED = 1.76). In conclusion, once-daily milking in early lactation may promote earlier resumption of ovarian cyclicity, mediated through improved nutritional status.

Key words: energy balance, milking frequency, reproduction

\section{INTRODUCTION}

The optimal use of grazed grass is a key component of profitability in Irish dairy production systems (Dillon

Received September 13, 2005

Accepted November 14, 2005.

${ }^{1}$ Corresponding author: jmurphy@moorepark.teagasc.ie et al., 1995). Compact seasonal calving in spring (late January to early April) is practiced to maximize the contribution of grazed grass to the feed requirements of the herd. This is achieved by restricting the breeding season to approximately $13 \mathrm{wk}$. The principal goal is to obtain the highest pregnancy rate in the shortest time to ensure a compact calving season and a 365$\mathrm{d}$ calving interval. The nutrient demands of lactation typically exceed dietary intake potential in the early postpartum period. This results in a state of negative energy balance (NEB), during which body tissue reserves are mobilized to provide additional substrate for milk production. Genetic selection for increased milk yield has amplified the difference between feed intake potential and milk yield potential in early lactation, resulting in cows that are genetically predisposed to a greater risk of NEB (Veerkamp and Koenen, 1999). It has been documented that the severity and duration of NEB are positively associated with the interval to first postpartum ovulation (Beam and Butler, 1999). In addition, it has been hypothesized that severe NEB in early lactation exerts latent negative effects on the quality of oocytes ovulated 80 to $100 \mathrm{~d}$ later, reducing conception rates in the first weeks of the breeding season (Britt, 1994). Minimizing the extent and duration of NEB in early lactation is an important factor for achieving optimum reproductive performance.

Increasing the proportion of dietary concentrate in early lactation has been shown to increase energy intake and improve energy balance (EB; Reist et al., 2003; Coffey et al., 2004). However, the proportion of concentrate in the diet is limited by the requirement for inclusion of structural fiber to maintain proper rumen function. In addition, cows of high genetic merit tend to partition additional ingested energy toward milk production, rather than reducing the extent of NEB (Veerkamp and Koenen, 1999). Given the difficulties associated with nutritional manipulation of EB in early lactation, interest in employing once-daily milking $(\mathbf{1} \times)$ to restrict milk energy output and moderate NEB has emerged. The imposition of temporary $1 \times$ in early lactation reduces milk yield, and exerts a negative residual effect upon resumption of twice-daily milking, the ex- 
tent of which becomes greater as the duration of the reduced milking frequency increases (Remond et al., 1999). Temporary $1 \times$ in early lactation does not affect DMI (McNamara, 2002; Remond et al., 2002). These studies reported that $1 \times$ cows had lower BCS and BW loss and a more positive EB than cows milked twice or 3 times daily. Pomies and Remond (2002) found that cows returned to positive EB much earlier, lost less BCS in early lactation, and maintained a higher BCS throughout lactation when milked once daily for the entire lactation compared with twice daily. The effects of $1 \times$ in early lactation on EB appear conducive to improved fertility. However, the direct effects on fertility have not been widely reported (McNamara, 2002). Increasing the energy density of the early lactation diet has produced variable responses regarding both EB and fertility. The objectives of this study were to investigate the effects of $1 \times$ and increased dietary energy density in early lactation on milk production, DMI, EB, BCS change, plasma metabolite concentrations, and subsequent reproductive function.

\section{MATERIALS AND METHODS}

\section{Animals and Experimental Design}

A cohort of 66 spring-calving, multiparous HolsteinFriesian cows was assembled 3 wk before expected calving date and trained to use the Griffith Elder feeding system (Griffith Elder Ltd., Bury St. Edmunds, Suffolk, UK). Cows were assigned to groups by 2 -wk expected calving intervals and allocated from within groups into blocks of 3 according to previous lactation milk yield and BCS. Cows were assigned at random from within blocks to 1 of 3 treatments in a randomized block design: 1) $1 \times$ milking at $0700 \mathrm{~h}$ for the first 4 wk of lactation, standard diet (ST), and twice-daily milking for the rest of the lactation; 2) 3-times daily milking $(\mathbf{3} \times)$ at 0700 , 1500 , and $2200 \mathrm{~h}$ for the first $4 \mathrm{wk}$ of lactation, on diet ST, and twice-daily milking for the rest of lactation; and 3) $3 \times$ milking at 0700,1500 , and $2200 \mathrm{~h}$ for the first $4 \mathrm{wk}$ of lactation, high-energy $\operatorname{diet}(\mathbf{H E})$, and twicedaily milking for the rest of the lactation.

The chemical composition of the silage and concentrates used over the duration of the trial is presented in Tables 1 and 2, respectively.

The cows were housed in a freestall barn, with the treatment groups sharing accommodation space throughout. Forage mangers were mounted on electronic load cells and automatic feeders dispensed concentrate. The prepartum diet comprised ad libitum access to grass silage with $2 \mathrm{~kg} / \mathrm{d}$ of citrus pulp introduced 2 wk before expected calving date. Treatments began on the morning after the second or third milking postcalving. Diet ST consisted of grass silage and $8 \mathrm{~kg} / \mathrm{d}$ of
Table 1. Chemical composition (mean \pm SD) of grass silage and corn silage

\begin{tabular}{lcc}
\hline & Grass silage & Corn silage \\
\hline $\mathrm{DM}(\mathrm{g} / \mathrm{kg})$ & $227 \pm 42.2$ & $229 \pm 16.1$ \\
$\mathrm{pH}$ & $3.9 \pm 0.13$ & $4.22 \pm 0.26$ \\
$\mathrm{CP}(\mathrm{g} / \mathrm{kg}$ of $\mathrm{DM})$ & $136 \pm 4.7$ & $103 \pm 5.1$ \\
$\mathrm{NDF}(\mathrm{g} / \mathrm{kg}$ of $\mathrm{DM})$ & $600 \pm 48.1$ & $565 \pm 30.8$ \\
Ash $(\mathrm{g} / \mathrm{kg}$ of $\mathrm{DM})$ & $71 \pm 6.0$ & $39 \pm 4.9$ \\
Starch $(\mathrm{g} / \mathrm{kg}$ of $\mathrm{DM})$ & $\mathrm{NA}^{1}$ & $140.9 \pm 18.5$ \\
$\mathrm{DM}$ digestibility $(\mathrm{g} / \mathrm{kg}$ of $\mathrm{DM})$ & $680 \pm 40$ & $710 \pm 26$ \\
Net energy $\left(\mathrm{UFL} / \mathrm{kg}\right.$ of $\left.\mathrm{DM}^{2}\right)$ & $0.78^{4}$ & $0.75^{5}$ \\
Net energy $^{3}(\mathrm{Mcal} / \mathrm{kg}$ of $\mathrm{DM})$ & 1.33 & 1.28 \\
\hline
\end{tabular}

${ }^{1} \mathrm{NA}=$ Not applicable.

${ }^{2} \mathrm{UFL}=$ Unité fourragère lait.

${ }^{3}$ Estimated based on $1 \mathrm{UFL}=1.7 \mathrm{Mcal} / \mathrm{kg}$ (Vermorel, 1989).

${ }^{4}$ The net energy value of silage was related to its in vitro DM digestibility concentration (O'Mara et al., 1997).

${ }^{5}$ The net energy value of corn was related to its estimated starch content (Jarrige, 1989).

concentrate. Diet HE consisted of grass and corn silage (1:2), plus $12 \mathrm{~kg} / \mathrm{d}$ of concentrate. Forage and concentrate allocations were fed separately. Cows had ad libitum access to forage, which was offered to allow for feed refusals of $5 \%$. Refusals were removed every second day. On d 29 postpartum, all cows were placed on a twice-daily milking schedule and allocated diet ST until turnout. Cows were provided access to pasture on d 42 postcalving and were offered high quality grass (Lolium perenne spp.) plus $4 \mathrm{~kg} / \mathrm{d}$ of concentrate, which was decreased to $2 \mathrm{~kg} / \mathrm{d}$ on d 21 after first service.

A voluntary waiting period of $65 \mathrm{~d}$ was observed before first service. An estrus induction program began

Table 2. Ingredient and chemical composition (mean \pm SD) of postcalving concentrate supplement

\begin{tabular}{lc}
\hline Ingredient & \\
\hline Barley $(\mathrm{g} / \mathrm{kg})$ & 200 \\
Beet pulp $(\mathrm{g} / \mathrm{kg})$ & 220 \\
Corn gluten $(\mathrm{g} / \mathrm{kg})$ & 170 \\
Rapeseed meal $(\mathrm{g} / \mathrm{kg})$ & 210 \\
Soybean meal $(\mathrm{g} / \mathrm{kg})$ & 140 \\
Lard $(\mathrm{g} / \mathrm{kg})$ & 30 \\
Dicalcium phosphate $(\mathrm{g} / \mathrm{kg})$ & 15 \\
Limestone flour $(\mathrm{g} / \mathrm{kg})$ & 7 \\
Salt $(\mathrm{g} / \mathrm{kg})$ & 5 \\
Calcined magnesite $(\mathrm{g} / \mathrm{kg})$ & 3 \\
Chemical composition & \\
DM (g/kg) & $868 \pm 36.8$ \\
CP $(\mathrm{g} / \mathrm{kg}$ of DM) & $202 \pm 69.6$ \\
NDF $(\mathrm{g} / \mathrm{kg}$ of DM) & $274 \pm 21.7$ \\
Ash $(\mathrm{g} / \mathrm{kg}$ of DM) & $91 \pm 2.4$ \\
Starch (g/kg of DM) & $178 \pm 14.6$ \\
Net energy (UFL/kg) & 1.0 \\
$\mathrm{NE}_{\mathrm{L}}{ }^{1}(\mathrm{Mcal} / \mathrm{kg})$ & 1.70 \\
\hline
\end{tabular}

${ }^{1}$ Estimated based on net energy values for ingredients (Jarrige, 1999); UFL = unité fourragère lait.

${ }^{2}$ Estimated based on $1 \mathrm{UFL}=1.7 \mathrm{Mcal} / \mathrm{kg}$ (Vermorel, 1989). 
on d 65 postpartum in cows not previously detected in estrus using a controlled internal drug-releasing insert (CIDR; InterAg, Hamilton, New Zealand) containing $1.94 \mathrm{~g}$ of progesterone, and an injection of $2 \mathrm{mg}$ of estradiol benzoate, $(5 \mathrm{mg} / \mathrm{mL}$; Intervet, Dublin, Ireland). The CIDR were removed on $\mathrm{d} 8$ and an injection of $\mathrm{PGF}_{2 \alpha}$ (2 mL of Estrumate; BP (Vet) Coopers, Berkhamsted, UK) was administered i.m. Cows received $1 \mathrm{mg}$ of estradiol benzoate $24 \mathrm{~h}$ after CIDR removal. Semen from a single ejaculate was used to breed all cows. One AI technician performed all inseminations. The duration of the breeding season was 13 wk.

\section{Samples and Animal Measurements}

Milk yield (kg) was recorded daily at morning, evening, and night milkings using electronic milk meters (Dairy Master, Causeway, Co. Kerry, Ireland). Milk composition (fat, protein, and lactose) was determined twice weekly from successive morning, evening, and night milk samples during the treatment period and weekly thereafter by automated infrared absorption analysis using a Milkoscan 605 (Foss Electric, Hillerød, Denmark). Somatic cell count was determined once weekly by flow cytometry using a Bentley Somacount 300 (Bentley Instruments Inc., Chaska, MN).

Forage and concentrate intakes were recorded using the Griffith Elder feeding system. Samples of grass silage and corn silage offered were taken on Tuesdays and Fridays. Concentrate samples were taken once weekly. The DMI was calculated daily.

Cow BW $(\mathrm{kg})$ was recorded once weekly before calving, immediately postcalving, and once weekly thereafter. The preparturient cows were weighed before feeding in the morning, and the lactating cows were weighed after morning milking, before feeding. The BCS (Lowman et al., 1976) of the cows was determined approximately 2 wk before calving to facilitate blocking, within $4 \mathrm{~d}$ after calving, and then once weekly until the end of the breeding season. Subcutaneous adipose tissue was recovered by biopsy (Robelin et al., 1986) on d 1 and 29 postpartum.

Blood samples were collected by jugular venipuncture 2 wk before expected calving date, twice weekly until d 28 postpartum, and once weekly from d 28 to d 70 postpartum. Sampling took place after morning milking and before feeding. Samples were collected into vials containing lithium heparin as an anticoagulant. The samples were immediately placed on ice packs, and were centrifuged at $2,000 \times \mathrm{g}$ for $10 \mathrm{~min}$ immediately after sampling. The plasma was decanted and stored at $-20^{\circ} \mathrm{C}$ until analysis.

Follicular dynamics and the diameter of the ovulatory dominant follicle were determined for each cow via daily transrectal ovarian ultrasonography $(7.5-\mathrm{MHz}$ transducer; Aloka SSD-500, Aloka Ltd., Tokyo, Japan) from d 7 postpartum until first ovulation. The interval from calving to first ovulation was determined based on ultrasound examination. Pregnancy examinations were conducted using ultrasonography at 30 and $60 \mathrm{~d}$ after $\mathrm{AI}$ and $60 \mathrm{~d}$ after the end of the breeding season. Estrus detection was carried out using the Heatwatch system (DDx Inc., Denver, CO) in conjunction with 3 daily visual observations at 0700, 1500, and $1900 \mathrm{~h}$, during and after the voluntary waiting period. Heatwatch transmitters were first applied $14 \mathrm{~d}$ postpartum. Milk samples for progesterone analysis were collected 3 times/wk during the morning milking from parturition until the start of the breeding season.

\section{Laboratory Procedures and Analysis}

The DM, NDF, crude fiber, and CP of the forage and concentrate samples were analyzed as described by McNamara et al. (2003). Determination of in vitro DM digestibility was carried out by near-infrared spectroscopy using a near infrared system 6500 spectrophotometer (Perstorp Analytical Inc., Silver Spring, MD). Silage $\mathrm{pH}$ on the juice pressed from the silage was measured using a glass electrode and a $\mathrm{pH}$ meter (pHM2 standard $\mathrm{pH}$ meter-radiometer, Radiometer, Copenhagen, Denmark).

Blood plasma was analyzed for glucose, triglycerides, NEFA, BHBA, urea, and cholesterol concentrations using appropriate kits and an ABX Mira auto analyzer (ABX Mira, Cedex 4, France). Insulin in plasma was assayed using a solid-phase radioimmunoassay (Coata-Count, Diagnostics Products Corp, Los Angeles, CA). The interassay coefficients of variation were 14.2 and $9.81 \%$ for samples with mean insulin concentrations of 6.4 and $13.1 \mu \mathrm{IU} / \mathrm{mL}$, respectively, and the corresponding intraassay coefficients of variation were 9.85 and $3.88 \%$. The minimum detectable concentration was 1.61 $\pm 0.03 \mu \mathrm{IU} / \mathrm{mL}$.

The concentration of progesterone in milk was measured by enzyme immunoassay from representative unextracted aliquots of whole milk as described by Sauer et al. (1986). The interassay coefficients of variation were $17.9,12.0$, and $12.2 \%$ for samples with mean progesterone concentrations of $2.34,4.06$, and $16.83 \mathrm{ng} /$ $\mathrm{mL}$, respectively, and the corresponding intraassay coefficients of variation were $8.89,3.27$, and $5.11 \%$. The minimum detectable concentration of the assay was 1.7 $\pm 0.52 \mathrm{ng} / \mathrm{mL}$.

Plasma samples (100 $\mu \mathrm{L}$ without extraction) were assayed for growth hormone using a modified form of the double-antibody radioimmunoassay of Hart et al. (1975). The inter- and intraassay coefficients of varia- 
tion were 12.2 and $7.6 \%$, respectively. The minimum detectable concentration of the assay was $2.6 \mathrm{ng} / \mathrm{mL}$.

Plasma IGF-I was measured using human OCTEIA IGF-I kits (IDS, Tyne and Wear, UK). Releasing reagent was added to dissociate IGF-I from binding proteins. The inter- and intraassay coefficients of variation were 8.7 and $2.1 \%$, respectively, and the sensitivity was $1.9 \mathrm{ng} / \mathrm{mL}$.

Subcutaneous adipose samples were processed as described by Robelin et al. (1986). Processed samples were photographed at $4 \times$ magnification using a standard light microscope and camera fitted with a C-mount adapter. Mean cell diameter was determined using Adobe Photoshop.

\section{Energy Balance}

Energy balance was estimated as the difference between energy intake and the sum of energy for maintenance and milk production, as described by McNamara et al. (2003). The French $\mathrm{NE}_{\mathrm{L}}$ system was used, in which 1 unité fourragère lait (UFL) is the net energy for lactation equivalent of $1 \mathrm{~kg}$ of standard air-dry barley (Jarrige, 1989).

\section{Statistical Analyses}

Five cows from $3 \times \mathrm{ST}$ [displaced abomasum (2), retained placenta (2), physical injury] and 2 cows from $3 \times \mathrm{HE}$ (displaced abomasum, retained placenta) were removed from the experiment. A smoothing spline was fit in Genstat 5 (1997; Lawes Agricultural Trust, IACRRothamstead, Harpenden, UK), to facilitate the estimation of daily BW records before analysis. Similarly, a smoothing spline was fit to calculate daily milk fat, protein, and lactose yields from which daily percentages were calculated. Somatic cell counts were transformed to logs before analysis.

Repeated measures of treatment effects on DMI, milk yield, milk constituent yield, milk composition, SCC, plasma analytes, and EB were carried out using the MIXED procedure of SAS (SAS Institute, 1991) with cow as a random effect nested within treatment. Treatment effects on BCS, adipocyte diameter, and BW change were analyzed using the GLM procedure. Treatment, time, and treatment $\times$ time interactions were tested. The reproduction data were analyzed using GLM (intervals to ovulation, service, and conception) and $\chi^{2}$ procedures (pregnancy rate to first and second services). Correlation coefficients between $\mathrm{EB}$ and some of the blood variables were obtained using the CORR procedure of SAS (SAS Institute, 1991).

\section{RESULTS}

\section{Milk Production and Composition}

Daily milk yield during the treatment period was reduced $(P<0.01)$ by $19.6 \%$ with $1 \times \mathrm{ST}$ compared with $3 \times \mathrm{ST}$ (Table 3 and Figure 1 ). Milk yield on $1 \times \mathrm{ST}$ increased with commencement of twice-daily milking in wk 5, but remained approximately $2 \mathrm{~kg} / \mathrm{d}$ lower than for $3 \times \mathrm{ST}$ throughout the first $20 \mathrm{wk}$ of the lactation. This resulted in an $11.7 \%$ lower $(P<0.03)$ mean cumulative milk yield at wk 10 for $1 \times \mathrm{ST}$. The cumulative reduction due to $1 \times$ was $11.3 \%(P<0.05)$ at wk 20 of lactation compared with $3 \times \mathrm{ST}$. Milk yield was increased by $17.0 \%$ $(P<0.01)$ with $3 \times \mathrm{HE}$ compared with $3 \times \mathrm{ST}$ during the treatment period. The change to twice-daily milking and allocation of the ST diet in wk 5 resulted in a reduction in milk yield for $3 \times \mathrm{HE}$, and the milk yields of $3 \times \mathrm{ST}$ and $3 \times \mathrm{HE}$ converged by wk 10 of lactation. The cumulative 10 -wk milk yield was $10.2 \%$ greater $(P<$ 0.05 ) for $3 \times \mathrm{HE}$ compared with $3 \times \mathrm{ST}$, but this had decreased to $5.9 \%(P>0.05)$ by wk 20 of lactation. Total lactation yields were $6,198,6,813$, and $7,132 \mathrm{~kg}$ on treatments $1 \times \mathrm{ST}, 3 \times \mathrm{ST}$, and $3 \times \mathrm{HE}$, respectively. This equated to a $615-\mathrm{kg}(P<0.05)$ difference due to milking frequency treatment, and a $319-\mathrm{kg}(P>0.05)$ difference due to dietary treatment.

Milk fat concentration was greatest $(P<0.01)$ with $1 \times$. This offset the reduced milk volume of the $1 \times \mathrm{ST}$ group, resulting in no difference $(P>0.05)$ in daily fat yield between the $1 \times \mathrm{ST}$ and $3 \times \mathrm{ST}$. Diet did not significantly affect milk fat concentration over the treatment period. However, $3 \times \mathrm{HE}$ increased $(P<0.01)$ daily fat yield by $21 \%$ compared with $3 \times \mathrm{ST}$.

Milk protein concentration was increased both by $1 \times \mathrm{ST}(P<0.01)$ and $3 \times \mathrm{HE}(P<0.05)$ compared with $3 \times$ ST. Daily protein yield was higher $(P<0.01)$ for $3 \times \mathrm{HE}$ than $3 \times \mathrm{ST}$, but reduced milk volume on $1 \times \mathrm{ST}$ resulted in lower $(P<0.05)$ daily protein yield compared with $3 \times$ ST. Milk protein concentration declined across all treatments in the $2 \mathrm{wk}$ posttreatment. However, protein concentration remained higher $(P<0.01)$ on $1 \times \mathrm{ST}$ compared with $3 \times \mathrm{ST}$, and diet had no effect $(P>0.05)$.

Milk lactose concentration was not affected by milking frequency or diet $(P>0.05)$. Hence, the significant differences observed for daily lactose yield during the treatment period were largely due to milk volume differences.

Daily milk energy output was lower $(P<0.05)$ for $1 \times \mathrm{ST}$ compared with $3 \times \mathrm{ST}$, and higher $(P<0.01)$ for $3 \times \mathrm{HE}$ compared with $3 \times \mathrm{ST}$ during the treatment period.

Somatic cell count was not affected by milking frequency, either during the trial period or in the posttreatment period $(P>0.05)$. 
Table 3. Effect of milking frequency and diet on milk and constituent yields, milk composition, and SCC

\begin{tabular}{|c|c|c|c|c|c|}
\hline & & Milkir & requency a & $\operatorname{diet}^{1}$ & \\
\hline & Week of lactation & $1 \times \mathrm{ST}$ & $3 \times \mathrm{ST}$ & $3 \times \mathrm{HE}$ & $\mathrm{SED}^{2}$ \\
\hline Milk yield (kg/d) & 1 to 4 & $21.7^{\mathrm{a}}$ & $27.0^{\mathrm{b}}$ & $31.6^{\mathrm{c}}$ & 1.45 \\
\hline & 5 to 6 & $26.8^{\mathrm{a}}$ & $26.7^{\mathrm{a}}$ & $30.7^{\mathrm{b}}$ & 1.38 \\
\hline & 10 Daily & $28.7^{\mathrm{a}}$ & $30.8^{\mathrm{ab}}$ & $32.2^{\mathrm{b}}$ & 1.51 \\
\hline & 10 Cumulative $(\mathrm{kg})$ & $1,682^{\mathrm{a}}$ & $1,880^{\mathrm{b}}$ & $2,094^{\mathrm{c}}$ & 83 \\
\hline & 20 Daily & $23.8^{\mathrm{a}}$ & $25.6^{\mathrm{ab}}$ & $26.3^{\mathrm{b}}$ & 0.98 \\
\hline & 20 Cumulative (kg) & $3,333^{\mathrm{a}}$ & $3,703^{b}$ & $3,935^{\mathrm{b}}$ & 162 \\
\hline & 305-d lactation total $(\mathrm{kg})$ & $6,198^{a}$ & $6,813^{\mathrm{b}}$ & $7,132^{b}$ & 304 \\
\hline Fat content $(\mathrm{g} / \mathrm{kg})$ & 1 to 4 & $47.1^{\mathrm{a}}$ & $40.7^{\mathrm{b}}$ & $42.2^{\mathrm{b}}$ & 1.61 \\
\hline & 5 to 6 & 42.0 & 40.0 & 39.0 & 1.67 \\
\hline Protein content $(\mathrm{g} / \mathrm{kg})$ & 1 to 4 & $35.5^{\mathrm{a}}$ & $32.2^{\mathrm{b}}$ & $34.0^{\mathrm{a}}$ & 0.87 \\
\hline & 5 to 6 & $30.8^{\mathrm{a}}$ & $28.6^{\mathrm{b}}$ & $28.5^{\mathrm{b}}$ & 0.80 \\
\hline Lactose content $(\mathrm{g} / \mathrm{kg})$ & 1 to 4 & 47.0 & 46.2 & 46.5 & 0.85 \\
\hline & 5 to 6 & $49.2^{\mathrm{a}}$ & $47.0^{\mathrm{b}}$ & $46.9^{\mathrm{b}}$ & 1.00 \\
\hline Fat yield $(\mathrm{kg} / \mathrm{d})$ & 1 to 4 & $1.02^{\mathrm{a}}$ & $1.09^{\mathrm{a}}$ & $1.33^{\mathrm{b}}$ & 0.06 \\
\hline & 5 to 6 & 1.13 & 1.06 & 1.20 & 0.07 \\
\hline Protein yield $(\mathrm{kg} / \mathrm{d})$ & 1 to 4 & $0.77^{\mathrm{a}}$ & $0.87^{\mathrm{b}}$ & $1.07^{\mathrm{c}}$ & 0.05 \\
\hline & 5 to 6 & $0.82^{\mathrm{ab}}$ & $0.76^{\mathrm{a}}$ & $0.87^{\mathrm{b}}$ & 0.04 \\
\hline Lactose yield $(\mathrm{kg} / \mathrm{d})$ & 1 to 4 & $1.02^{\mathrm{a}}$ & $1.25^{\mathrm{b}}$ & $1.47^{\mathrm{c}}$ & 0.07 \\
\hline & 5 to 6 & $1.32^{\mathrm{ab}}$ & $1.26^{\mathrm{a}}$ & $1.43^{\mathrm{b}}$ & 0.07 \\
\hline Milk energy (UFL/d) $)^{3}$ & 1 to 4 & $10.4^{\mathrm{a}}$ & $11.7^{\mathrm{b}}$ & $14.1^{\mathrm{c}}$ & 0.62 \\
\hline & 5 to 6 & $11.9^{\mathrm{ab}}$ & $11.2^{\mathrm{a}}$ & $12.7^{\mathrm{b}}$ & 0.66 \\
\hline $\operatorname{SCC}(\log / \mathrm{mL})$ & 1 to 4 & 5.08 & 5.67 & 5.09 & 0.43 \\
\hline & 5 to 6 & 4.86 & 5.35 & 5.15 & 0.79 \\
\hline
\end{tabular}

${ }^{\mathrm{a}-\mathrm{c}}$ Means within rows having different superscripts differ significantly $(P<0.05)$.

${ }^{1} 1 \times \mathrm{ST}=$ once a day milking for the first $4 \mathrm{wk}$ of lactation on standard diet; $3 \times \mathrm{ST}=3$ times a day milking for the first $4 \mathrm{wk}$ of lactation on standard diet; $3 \times \mathrm{HE}=3$ times a day milking for the first 4 wk of lactation on a high-energy diet.

${ }^{2} \mathrm{SED}=$ Standard error of difference.

${ }^{3} \mathrm{UFL}=$ Unité fourragère lait.

\section{DMI, Net Energy Intake, and EB}

Feeding the HE diet increased $(P<0.05)$ DMI during the treatment period, whereas milking frequency had no effect $(P>0.05$; Figure 2$)$. However, DMI was lower $(P<0.05)$ for $1 \times$ ST than $3 \times$ ST in wk 4 . The DMI of the

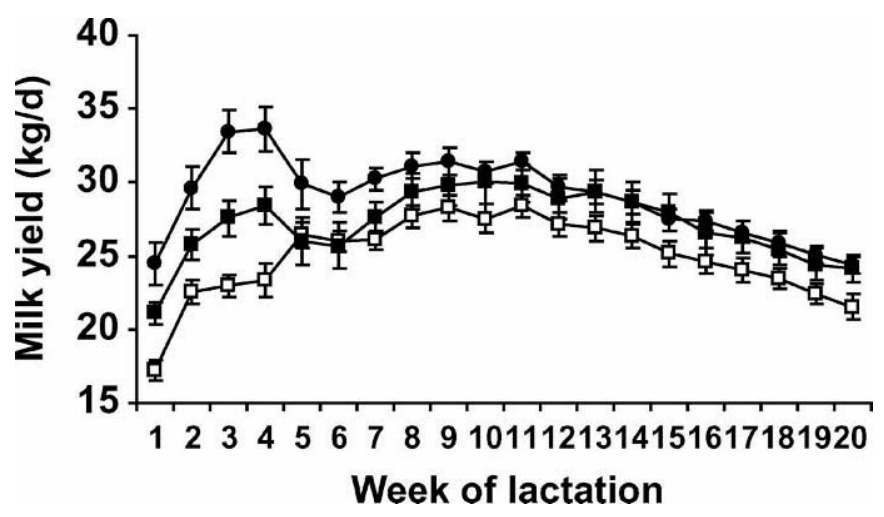

Figure 1. Effect of milking frequency and diet on milk production for wk 1 to 20 of lactation; $1 \times \mathrm{ST}(\square)=$ once a day milking for the first $4 \mathrm{wk}$ of lactation on standard diet; $3 \times \mathrm{ST}(\boldsymbol{\square})=3$ times a day milking for the first $4 \mathrm{wk}$ of lactation on standard diet; $3 \times \mathrm{HE}(\bullet)=$ 3 times a day milking for the first 4 wk of lactation on a highenergy diet. milking frequency groups converged upon commencement of twice-daily milking. There were no residual milking frequency or diet effects $(P>0.05)$ in the 2 wk posttreatment.

Daily EB for $1 \times$ ST was less negative $(P<0.05)$ than for $3 \times$ ST during the first $3 \mathrm{wk}$ of lactation, though this difference was not apparent in wk $4(P>0.05)$. There were no differences in EB observed due to dietary treatment $(P>0.05)$ during the treatment period.

\section{BW, BCS, and Adipocyte Diameter}

Neither milking frequency $(P>0.05)$ nor dietary treatment $(P>0.05)$ affected the degree of BW change during the treatment period (Table 4). However, cows on $1 \times \mathrm{ST}$ began to gain weight earlier postpartum. Consequently, they lost less $(P<0.01)$ weight than cows on $3 \times$ ST by d 60 of lactation. There was no residual dietary treatment effect on BW loss.

Neither milking frequency nor dietary treatment altered BCS loss during the treatment period $(P>0.05$; Table 4). The BCS loss for all groups during the treatment period was approximately 0.25 units. By the start of the breeding season the mean BCS loss was approximately 0.5 units for all groups $(P>0.05)$. Change in 


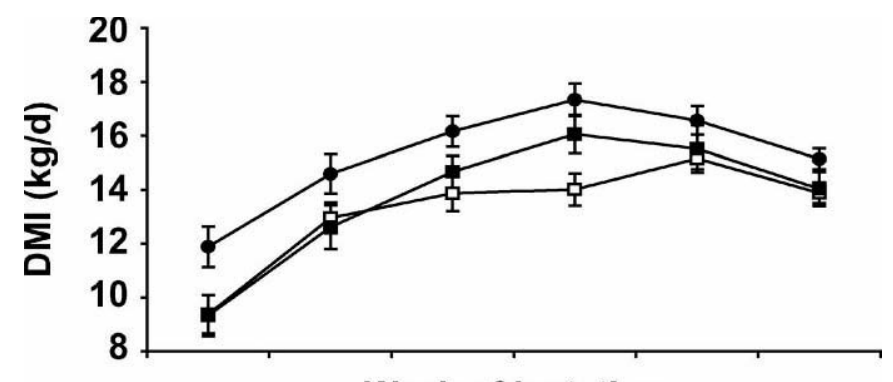

Week of lactation

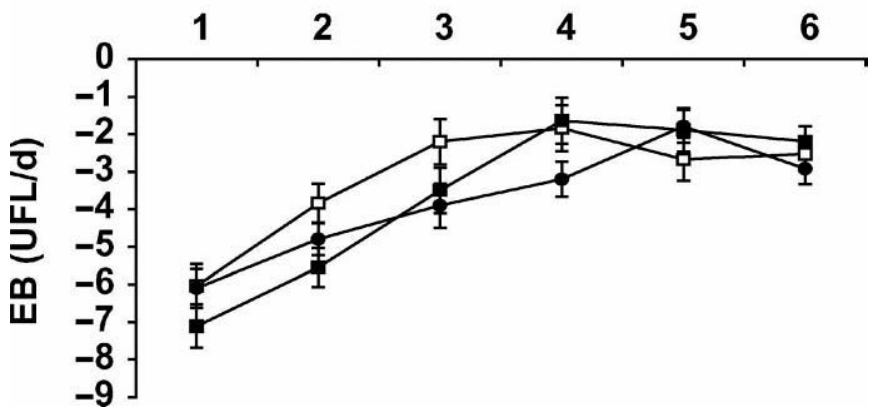

Figure 2. Effect of milking frequency and diet on DMI and energy balance (EB); 1×ST $(\square)=$ once a day milking for the first 4 wk of lactation on standard diet; $3 \times \mathrm{ST}(\boldsymbol{\square})=3$ times a day milking for the first 4 wk of lactation on standard diet; $3 \times \mathrm{HE}(\mathbf{0})=3$ times a day milking for the first $4 \mathrm{wk}$ of lactation on a high-energy diet. UFL = Unité fourragère lait.

mean adipocyte diameter over the treatment period tended to be lower $(P=0.07)$ for $1 \times \mathrm{ST}$ compared with $3 \times \mathrm{ST}$. Change in mean adipocyte diameter over the

Table 4. Effect of milking frequency and diet on BW, BCS, and adipocyte diameter

\begin{tabular}{|c|c|c|c|c|}
\hline & \multicolumn{3}{|c|}{ Milking frequency and $\operatorname{diet}^{1}$} & \multirow[b]{2}{*}{ SED } \\
\hline & $1 \times \mathrm{ST}$ & $3 \times \mathrm{ST}$ & $3 \times \mathrm{HE}$ & \\
\hline \multicolumn{5}{|l|}{ BW $(\mathrm{kg})$} \\
\hline d 0 to 28 & -17.8 & -29.3 & -32.0 & 8.1 \\
\hline d 0 to 42 & $-16.9^{\mathrm{a}}$ & $-35.7^{\mathrm{ab}}$ & $-39.9^{b}$ & 10.6 \\
\hline d 0 to 60 & $0.1^{\mathrm{a}}$ & $-36.3^{\mathrm{b}}$ & $-36.6^{\mathrm{b}}$ & 9.8 \\
\hline \multicolumn{5}{|l|}{$\mathrm{BCS}^{3}$} \\
\hline d 0 to 28 & -0.30 & -0.29 & -0.24 & 0.11 \\
\hline d 0 to 42 & -0.42 & -0.34 & -0.46 & 0.13 \\
\hline d 0 to 70 & -0.52 & -0.49 & -0.54 & 0.16 \\
\hline d 0 to 120 & -0.57 & -0.53 & -0.69 & 0.14 \\
\hline \multicolumn{5}{|l|}{ Adipocyte diameter $(\mu \mathrm{m})$} \\
\hline d 0 & 134 & 138 & 139 & 7.1 \\
\hline d 28 & $124^{\mathrm{a}}$ & $112^{\mathrm{ab}}$ & $109^{b}$ & 7.9 \\
\hline d 0 to 28 & $-10^{a}$ & $-26^{\mathrm{ab}}$ & $-30^{\mathrm{b}}$ & 8.6 \\
\hline
\end{tabular}

${ }^{\mathrm{a}, \mathrm{b}}$ Means within rows having different superscripts differ significantly $(P<0.05)$

${ }^{1} 1 \times \mathrm{ST}=$ once a day milking for the first $4 \mathrm{wk}$ of lactation on standard diet; $3 \times \mathrm{ST}=3$ times a day milking for the first $4 \mathrm{wk}$ of lactation on standard diet; $3 \times \mathrm{HE}=3$ times a day milking for the first $4 \mathrm{wk}$ of lactation on a high-energy diet.

${ }^{2} \mathrm{SED}=$ Standard error of difference.

${ }^{3}$ As measured by Lowman et al. (1976).
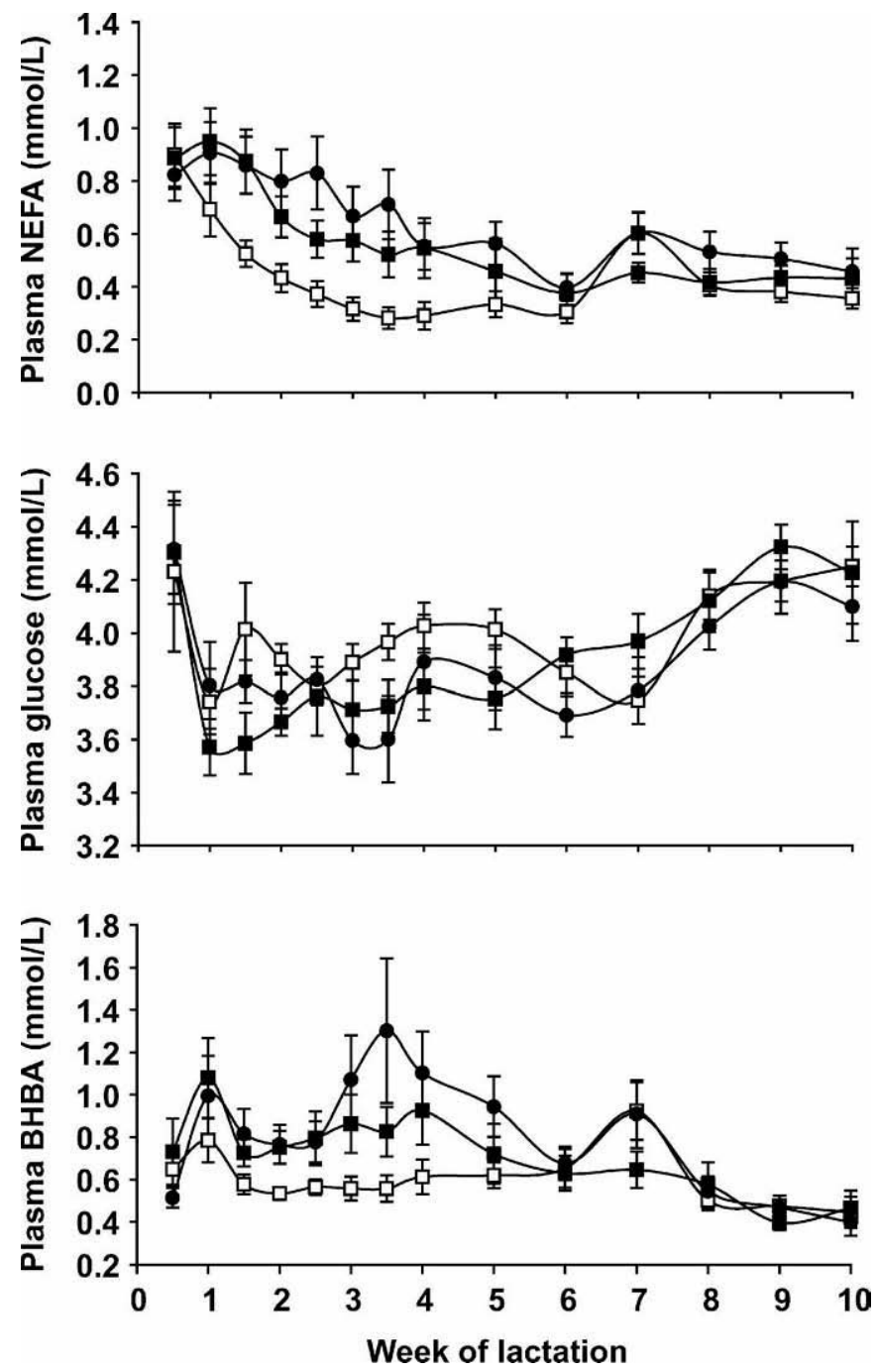

Figure 3. Effect of milking frequency and diet on plasma NEFA, glucose and BHBA concentration; $1 \times \mathrm{ST}(\square)=$ once a day milking for the first 4 wk of lactation on standard diet; $3 \times \mathrm{ST}(\mathbf{\square})=3$ times a day milking for the first $4 \mathrm{wk}$ of lactation on standard diet; $3 \times \mathrm{HE}(\bullet)=$ 3 times a day milking for the first 4 wk of lactation on a highenergy diet.

treatment period was not different $(P>0.05)$ between the $3 \times \mathrm{HE}$ and $3 \times \mathrm{ST}$ groups (Table 4 ).

\section{Plasma Analytes}

Plasma glucose concentration was higher $(P<0.01)$ during wk 2 for $1 \times \mathrm{ST}$ compared with $3 \times \mathrm{ST}$ (Figure 3 ). Plasma NEFA was lower $(P<0.05)$ for $1 \times$ ST compared with $3 \times$ ST over the treatment period. Similarly, plasma BHBA was lower $(P<0.05)$ for $1 \times$ ST compared with $3 \times \mathrm{ST}$ at this time. Daily EB was positively correlated with plasma concentrations of cholesterol $(\mathrm{r}=0.34 ; P$ $<0.01$ ), and negatively correlated with plasma concen- 
Table 5. Effect of milking frequency and diet on mean plasma concentration of cholesterol, triglyceride, and urea during the first 4 wk of lactation

\begin{tabular}{lllll}
\hline & \multicolumn{3}{c}{ Milking frequency and diet } & \\
\cline { 2 - 3 } & $1 \times \mathrm{ST}$ & $3 \times \mathrm{ST}$ & $3 \times \mathrm{HE}$ & $\mathrm{SED}^{2}$ \\
\hline Cholesterol $(\mathrm{mmol} / \mathrm{L})$ & 3.15 & 2.85 & 3.10 & 0.18 \\
Triglyceride $(\mathrm{mmol} / \mathrm{L})$ & 0.18 & 0.17 & 0.16 & 0.01 \\
Urea (mmol/L) & 4.44 & 4.32 & 4.40 & 0.26 \\
\hline
\end{tabular}

${ }^{1} 1 \times \mathrm{ST}=$ once a day milking for the first $4 \mathrm{wk}$ of lactation on standard diet; $3 \times \mathrm{ST}=3$ times a day milking for the first $4 \mathrm{wk}$ of lactation on standard diet; $3 \times \mathrm{HE}=3$ times a day milking for the first $4 \mathrm{wk}$ of lactation on high energy diet.

${ }^{2} \mathrm{SED}=$ Standard error of difference.

trations of BHBA $(\mathrm{r}=-0.18 ; P<0.01)$ and NEFA $(\mathrm{r}=$ $-0.45 ; P<0.01)$. Plasma concentrations of urea and triglyceride were not affected by milking frequency treatment $(P>0.05$; Table 5). Dietary treatment had no effects on any of the plasma metabolites measured $(P>0.05)$. Plasma insulin concentration during the treatment period was higher $(P<0.05$, Figure 4$)$ for $1 \times \mathrm{ST}$ than $3 \times \mathrm{ST}$ ( 2.25 vs. $1.27 \mu \mathrm{IU} / \mathrm{mL}$; SED = 0.48). No differences in plasma insulin were evident in the first week of lactation $(P>0.05)$, but $1 \times$ increased $(P<$ 0.01 ) plasma insulin during wk 2 to 4 . No residual effects of milking frequency on plasma insulin were apparent after wk 5 of lactation $(P>0.05)$. Plasma insulin concentration was not affected by diet over the treatment period or in the posttreatment period $(P>$ 0.05).

Plasma IGF-I tended $(P=0.08)$ to be greater on $1 \times \mathrm{ST}$ compared with $3 \times$ ST over the treatment period. Feeding the HE diet did not affect plasma IGF-I concentrations $(P>0.05$; Figure 4$)$. There were no posttreatment effects on IGF-I. No difference in growth hormone concentration was observed between the milking frequency treatments $(P>0.05)$.

\section{Fertility Measurements}

The interval to first ovulation, as measured by ultrasound scanning, was shorter $(P<0.01)$ for $1 \times \mathrm{ST}$ compared with $3 \times \mathrm{ST}$ (Table 6 ), with a higher proportion $(P$ $<0.05)$ of $1 \times \mathrm{ST}$ cows ovulating the first postpartum dominant follicle. Dietary treatment did not affect interval to first ovulation or the proportion of cows ovulating the first postpartum dominant follicle $(P>0.05)$. The onset of luteal activity, as measured by milk progesterone, was earliest for $1 \times \mathrm{ST}(P<0.05)$ compared with $3 \times \mathrm{ST}$, with no difference $(P>0.05)$ due to dietary treatment. There were no treatment effects on interovulatory interval $(P>0.05)$ or the duration of the luteal phase $(P>0.05)$. Neither milking frequency nor diet had any effects on intervals to conception, conception
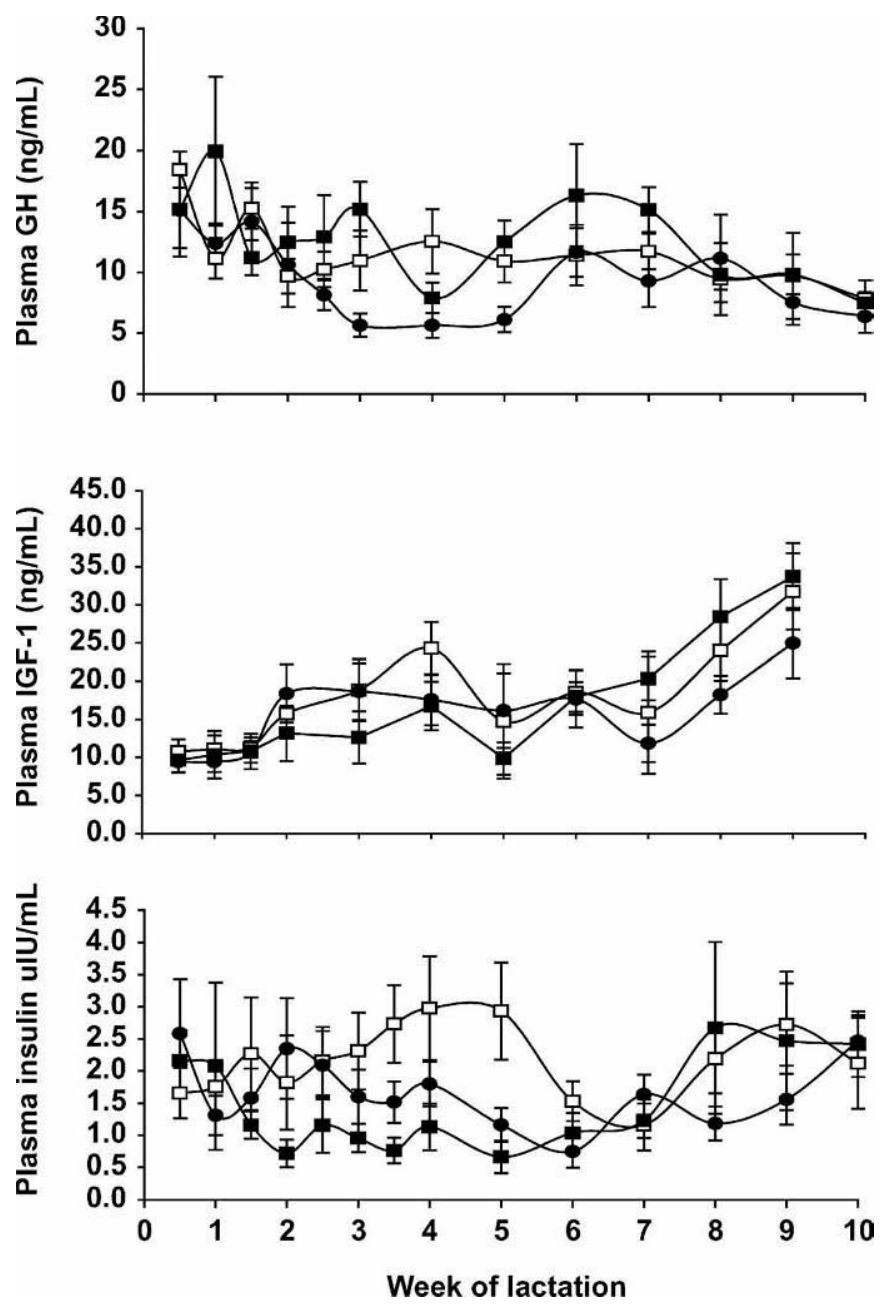

Figure 4. Effect of milking frequency and diet on plasma growth hormone (GH), IGF-I and insulin concentration; $1 \times \mathrm{ST}(\square)=$ once a day milking for the first 4 wk of lactation on standard diet; $3 \times \mathrm{ST}$ (घ) $=3$ times a day milking for the first 4 wk of lactation on standard diet; $3 \times \mathrm{HE}(\bullet)=3$ times a day milking for the first $4 \mathrm{wk}$ of lactation on a high-energy diet.

rates to first or second service, or overall pregnancy rate $(P>0.05)$.

\section{DISCUSSION}

In general, $1 \times$ did not create difficulties for routine management of the cows. Somatic cell counts and the incidence of clinical mastitis were not affected. The degree of reduction in milk yield was generally similar to previous studies (Remond et al., 1999; McNamara, 2002). The effects of feeding the HE diet on milk yield and milk protein concentrations are consistent with the well-documented responses to a reduction of the forageto-concentrate ratio (Ferris et al., 2001), and inclusion of corn silage in grass silage-based diets (Phipps et al., 
Table 6. Effect of milking frequency and diet on reproductive performance

\begin{tabular}{llllr}
\hline & \multicolumn{3}{c}{ Milking frequency and diet $^{1}$} & \\
\cline { 2 - 4 } & $1 \times \mathrm{ST}$ & $3 \times \mathrm{ST}$ & $3 \times \mathrm{HE}$ & SED $^{2}$ \\
\hline Interval to first ovulation $^{3}(\mathrm{~d})$ & $18.3^{\mathrm{a}}$ & $28.6^{\mathrm{b}}$ & $32.7^{\mathrm{b}}$ & 1.76 \\
Onset of luteal activity $^{4}(\mathrm{~d})$ & $22.1^{\mathrm{a}}$ & $31.5^{\mathrm{b}}$ & $34.4^{\mathrm{b}}$ & 4.08 \\
Luteal phase (d) $_{\text {Interovulatory interval (d) }}^{14.8}$ & 12.8 & 13.3 & 2.6 \\
Calving to conception interval (d) & 23.6 & 23.9 & 23.1 & 2.75 \\
Conception rate to first service (\%) & 96 & 96 & 98 & 10.47 \\
Overall pregnancy rate (\%) & $50(11 / 22)$ & $65(11 / 17)$ & $65(13 / 20)$ & - \\
Cows ovulating first dominant follicle (\%) & $86(19 / 22)$ & $94(16 / 17)$ & $90(18 / 20)$ & - \\
\hline
\end{tabular}

\footnotetext{
on high energy diet.

${ }^{2} \mathrm{SED}=$ Standard error of difference.

${ }^{3}$ Measured by daily ultrasound scanning.

${ }^{4}$ Measured by milk progesterone.
}

${ }^{\mathrm{a}, \mathrm{b}}$ Means within rows having different superscripts differ significantly $(P<0.05)$.

${ }^{1} 1 \times \mathrm{ST}=$ once a day milking for the first $4 \mathrm{wk}$ of lactation on standard diet; $3 \times \mathrm{ST}=3$ times a day milking for the first $4 \mathrm{wk}$ of lactation on standard diet; $3 \times \mathrm{HE}=3$ times a day milking for the first 4 wk of lactation

1995). The negative residual effects on milk yield of $1 \times$ may be attributable to impaired mammary epithelial cell proliferation and differentiation. There is a strong relationship between milk yield and number of mammary epithelial cells (Tucker, 1981). Increasing milking frequency in early lactation was shown to increase mammary cell proliferation (Hale et al., 2003).

As expected, increasing the proportion of concentrate and including corn silage in the diet increased DMI (Phipps et al., 1995; Ferris et al., 2001). However, daily DMI over the treatment period was not affected by milking frequency. The lower DMI of $1 \times \mathrm{ST}$ in wk 4 suggests that an effect was beginning to emerge, but commencement of twice daily milking for both groups in wk 5 resulted in the convergence of DMI. The results indicate that continuation of $1 \times$ over a more prolonged period would lead to lower daily DMI, as has been observed where cows were milked once daily over a full lactation (Pomies and Remond, 2002).

Once-daily milking resulted in a more positive EB during the first 3 wk of lactation. This difference was not apparent in wk 4, presumably due to the lower DMI of $1 \times \mathrm{ST}$ at that time. The improvement in EB of approximately $1 \mathrm{UFL} / \mathrm{d}$ over the treatment period was less marked than previously documented (Remond et al., 1999, 2002; McNamara, 2002). These authors reported that cows milked once daily were approaching positive EB by the third week of lactation. In contrast, the mean daily EB of the $1 \times$ cows in the current study did not become positive at any time during the first 6 wk of lactation.

Variation in EB is largely explained by variation in energy intake, and to a lesser extent by milk yield (VillaGodoy et al., 1988). Where improvements in EB due to $1 \times$ have been observed (McNamara, 2002; Remond et al., 2002), the quality of diet offered and DMI achieved were higher than in the current study. The effect of $1 \times$ on EB may therefore be dependent on plane of nutrition.

Increasing the energy density of the diet in early lactation did not improve EB, as milk energy output of cows offered the HE diet increased by a similar magnitude to net energy intake. Other studies have demonstrated a positive relationship between proportion of concentrate in the lactating diet and EB (Reist et al., 2003; Coffey et al., 2004). The 4-wk duration of the HE diet was shorter than for the studies cited above, and it coincided with the stage of lactation when maximal partitioning of available energy to milk production was occurring (Bell, 1995).

Cows milked once daily began to gain BW sooner than $3 \times$ cows, resulting in lower cumulative BW loss at $d 60$ of lactation. The earlier resumption of weight gain in $1 \times \mathrm{ST}$ cows may be due to an improved EB, brought about by the negative residual effect on daily milk yield.

Subcutaneous adipocyte diameter is positively related to body fat content (Robelin et al., 1986). Despite the similarity in BCS profiles of the treatment groups, the $1 \times$ ST cows had a smaller reduction in subcutaneous adipocyte diameter compared with that of the $3 \times \mathrm{ST}$ and $3 \times \mathrm{HE}$ cows. This indicates that the improvement in $\mathrm{EB}$ due to $1 \times$ was sufficient to reduce body fat mobilization, despite being undetected by body condition scoring. Furthermore, the lower plasma NEFA concentration of the $1 \times \mathrm{ST}$ cows compared with the $3 \times \mathrm{ST}$ and $3 \times \mathrm{HE}$ groups is consistent with a lesser degree of body fat mobilization.

Plasma insulin increases in response to elevated blood glucose concentration, and is positively associated with EB in the early postpartum period (Diskin et al., 
2003). Numerous studies have shown that cows in a more positive EB have greater circulating concentrations of IGF-I (Spicer et al., 1990; Beam and Butler, 1999), contrary to the current study. Once-daily milking reduced plasma NEFA concentration, indicating a positive effect on EB (Diskin et al., 2003). In addition, $1 \times \mathrm{ST}$ increased plasma insulin concentrations in line with the positive effects observed on energy status and metabolite profiles.

Daily ultrasound scanning and milk progesterone profiling showed that $1 \times \mathrm{ST}$ cows resumed cyclicity 10 $\mathrm{d}$ earlier than $3 \times \mathrm{ST}$ and $3 \times \mathrm{HE}$ cows, due to a higher proportion of cows having ovulated the dominant follicle of the first follicular wave. Daily EB during wk 2 and 3 was less negative for the $1 \times$ ST group, coincident with the mean day of first postpartum ovulation. Beam and Butler (1999) reported that cows with a shorter interval to EB nadir and a more positive EB during the first 3 wk of lactation had a reduced interval to first ovulation.

Plasma insulin and glucose concentrations were higher for $1 \times \mathrm{ST}$ around the time of first ovulation. Glucose is an important metabolic factor regulating the onset of cyclicity; increased plasma glucose promotes $\mathrm{LH}$ release through its effects on GnRH secretion (Diskin et al., 2003). Insulin has been identified as having stimulatory effects on granulosa cell proliferation, estradiol production by granulosa cells, as well as androgen production by thecal cells (Spicer and Echternkamp, 1995). In summary, the effects of once daily milking on early postpartum metabolic status were conducive to enhanced follicular development and earlier onset of cyclicity.

Early reestablishment of ovarian activity allows for the completion of multiple ovulatory cycles preceding insemination, which has been linked to improved conception rates (Darwash et al., 1997). However, this factor becomes important only when intervals to first ovulation exceed about $40 \mathrm{~d}$. In this study the majority (87\%) of cows had resumed cyclicity by $40 \mathrm{~d}$, and conception rate and final pregnancy rate did not differ due to milking frequency, despite the earlier onset of cyclicity for the $1 \times$ ST group.

\section{CONCLUSIONS}

Increasing the energy density of the early lactation diet resulted in higher DMI. However, EB was not improved, as additional ingested nutrients were partitioned toward milk production. Temporary $1 \times$ in early lactation reduced milk yield and increased milk fat and protein concentrations. There was a residual negative effect on milk yield, which persisted through the first half of lactation for $1 \times \mathrm{ST}$ compared with $3 \times \mathrm{ST}$ cows. Milking frequency did not affect DMI, and calculated
EB tended to be less negative for $1 \times \mathrm{ST}$ cows for the first $3 \mathrm{wk}$. Improvement in metabolic status was further evidenced by increased plasma concentrations of glucose and insulin and reduced concentrations of plasma NEFA. The findings of this study demonstrate that once-daily milking may be an effective strategy for reducing the incidence of delayed resumption of cyclicity associated with nutritional stress in early lactation at the cost of reduced milk yield.

\section{ACKNOWLEDGMENTS}

The authors would like to thank J. P. Murphy, J. Keneally, and the Moorepark farm staff for management and care of the animals. The technical assistance of T. Condon, J. Dwyer, N. Galvin, N. Hynes, J. Haugh, and S. Llewellyn is also appreciated. Wellcome Trust and National Development Plan funding is gratefully acknowledged.

\section{REFERENCES}

Beam, S. W., and W. R. Butler. 1999. Effects of energy balance on follicular development and first ovulation in postpartum dairy cows. J. Reprod. Fertil. Suppl. 54:411-424.

Bell, A. W. 1995. Regulation of organic nutrient metabolism during transition from late pregnancy to early lactation. J. Anim. Sci. 73:2804-2819.

Britt, J. H. 1994. Impacts of early postpartum metabolism on follicular development and fertility. Bovine Pract. 24:39-43.

Coffey, M. P., G. Simm, J. D. Oldham, W. G. Hill, and S. Brotherstone. 2004. Genotype and diet effects on energy balance in the first three lactations of dairy cows. J. Dairy Sci. 87:4318-4326.

Darwash, A. O., J. A. Wooliams, and G. E. Lamming. 1997. The phenotypic association between the interval to postpartum ovulation and traditional measures of fertility in dairy cattle. Anim. Sci. 65:9-16.

Dillon, P. G., S. Crosse, G. Stakelum, and F. Flynn. 1995. The effect of calving date and stocking rate on the performance of springcalving dairy cows. Grass Forage Sci. 50:286-299.

Diskin, M. G., D. R. Mackey, J. F. Roche, and J. M. Sreenan. 2003. Effects of nutrition and metabolic status on circulating hormones and ovarian follicle development in cattle. Anim. Reprod. Sci. 78:345-370.

Ferris, C. P., F. J. Gordon, D. C. Patterson, D. J. Kilpatrick, C. S. Mayne, and M. A. McCoy. 2001. The response of dairy cows of high genetic merit to increasing proportion of concentrate in the diet with a high and medium feed value silage. J. Agric. Sci. 136:319-329.

Hale, S. A., A. V. Capuco, and R. A. Erdman. 2003. Milk yield and mammary growth effects due to increased milking frequency during early lactation. J. Dairy Sci. 86:2061-2071.

Hart, I., D. S. Flux, P. Andrews, and A. S. McNeilly. 1975. Radioimmunoassay for ovine and caprine growth hormone: Its application to the measurement of basal circulating levels of growth hormone in the goat. Horm. Metab. Res. 7:35-40.

Jarrige, J. 1989. INRAtion V2.7.: Microsoft computer program of ration formulation for ruminant livestock. J. Agabriel, P. Champciaux, and C. Espinasse, ed. CNERTA, Dijon, France.

Lowman, B. G., N. Scott, and S. Somerville. 1976. Condition scoring of cattle. Rev. ed. Bull. East Scotland College Agric. No. 6. Edinburgh, UK.

McNamara, S. 2002. Effect of nutrition in the transition and early post partum period on some aspects of production and reproduction in dairy cows. Ph.D. Thesis, Natl. Univ. Ireland, Dublin, Ireland. 
McNamara, S., F. P. O'Mara, M. Rath, and J. J. Murphy. 2003. Effects of different transition diets on dry matter intake, milk production, and milk composition in dairy cows. J. Dairy Sci. 86:2397-2408.

O'Mara, F. P., P. J. Caffrey, and M. J. Drennan. 1997. The net energy value of grass silage determined from comparative feeding trials. Irish J. Agric. Food Res. 36:110. (Abstr.)

Phipps, R. H., J. D. Sutton, and B. A. Jones. 1995. Forage mixtures for dairy cows: The effect on dry matter intake and milk production of incorporating either fermented or urea-treated whole-crop wheat, brewers grain, fodder beet or maize silage with diets based on grass silage. Anim. Sci. 61:491-496.

Pomies, D., and B. Remond. 2002. Once a day milking of dairy cows during the whole lactation: Consequences on performance and milk quality. Pages 195-198 in 9emes Rencontres autour des recherches sur les ruminants. INRA, Paris, France.

Reist, M., D. Erdin, D. von Euw, K. Tschuemperlin, H. Leuenberger, C. Delavaud, Y. Chilliard, H. M. Hammon, N. Kuenzi, and J. W. Blum. 2003. Concentrate feeding strategy in lactating dairy cows: Metabolic and endocrine changes with emphasis on leptin. J. Dairy Sci. 86:1690-1706.

Remond, B., S. Aubailly, Y. Chilliard, D. Dupont, D. Pomies, and M. Petit. 2002. Combined effects of once-daily milking and feeding level in the first three weeks of lactation on milk production and enzyme activities, and nutritional status, Holstein cows. Anim. Res. 51:101-117.

Remond, B., J. B. Coulon, M. Nicloux, and D. Levieux. 1999. Effect of temporary once daily milking in early lactation on milk production and nutritional status of dairy cows. Ann. Zootech. (Paris) 48:341-352.
Robelin, J., J. Agabriel, C. Barboiron, R. Jailler, G. Cuylle, and G. Moins. 1986. Estimation de l'etat d'engraissement des bovins vivants a partir de la taille des cellules adipeuses. Bull. Tech. C.R.Z.V Theix, INRA 66:37-41.

SAS Institute. 1991. SAS User's Guide. Statistics,. Version 8.1. SAS Inst., Inc., Cary, NC.

Sauer, M. J., J. A. Foulkes, A. Worsfold, and B. A. Morris. 1986. Use of progesterone 11-glucuronide-alkine phosphatase conjugate in a sensitive microtitre-plate enzyme immunoassay of progesterone in milk and its application to pregnancy testing in dairy cattle. J. Reprod. Fertil. 76:375-391.

Spicer, L. J., and S. E. Echternkamp. 1995. The ovarian insulin and insulin-like growth factor system with emphasis on domestic animals. Domest. Anim. Endocrinol. 12:223-245.

Spicer, L. J., W. B. Tucker, and G. D. Adams. 1990. Insulin-like growth factor in dairy cows: Relationships among energy balance, body condition, ovarian activity, and estrous behavior. J. Dairy Sci. 73:929-937.

Tucker, H. A. 1981. Physiological control of mammary growth, lactogenesis and lactation. J. Dairy Sci. 64:1403-1421.

Veerkamp, R. F., and E. P. C. Koenen. 1999. Genetics of food intake, live weight, condition score and energy balance. Occ. Pub. Br. Soc. Anim. Sci. no. 24, Br. Soc. Anim. Sci., Edinburgh, UK.

Vermorel, M. 1989. Energy: The feed unit system. Pages 23-32 in Ruminant Nutrition-Recommended Allowances and Feed Tables. R. Jarrige, ed. John Libbey Eurotext, Paris, France.

Villa-Godoy, A., T. L. Hughes, R. S. Emery, L. T. Chapin, and R. L. Fogwell. 1988. Association between energy balance and luteal function in lactating dairy cows. J. Dairy Sci. 71:1063-1072. 